\title{
Change detection analysis of Cropland using Geospatial technique -A case Study of Narsinghpur District
}

\author{
Upadhyay Renu, Nema R.K., Awasthi M.K., Tiwari, Y.K.
}

\begin{abstract}
Department of soil and Water Engineering, college of Agricultural Engineering, J.N.K.V.V., Jabalpur-482004 (M.P.)-India
\end{abstract}
\begin{abstract}
Access to accurate and up-to-date information on the extent and distribution of individual crop types, associated with land use changes and practices, has significant value in intensively agricultural regions. Explicit information of croplands can be useful for sustainable water resources, land and agriculture planning and management. Remote sensing, has been proven to be a more cost-effective alternative to the traditional statistically-based ground surveys for crop coverage areas that are costly and provide insufficient information. Satellite images along with ground surveys can provide the necessary information of spatial coverage and spectral responses of croplands for sustainable agricultural management. This study strives to differentiate different crop types and agricultural practices to achieve a higher detailed crop map of the Narsinghpur district.
\end{abstract}

Keywords - Change detection, Satellite imagery, Crop cover, Supervised Classification technique, Remote Sensing and GIS.

\section{INTRODUCTION}

Observation and assessment of crop status and development is a crucial topic for agronomic planning and management and for mitigating the effects induced by climate change and extreme events. In order to meet the need of increasing population demand, the timely and precise information on the area covered by different crops is quite necessary (Foerster et al., 2012; Conrad et al., 2014).

In particular, in-season crop type maps produced during early growth stages are the key information source for operational agricultural monitoring by both public authorities and private sectors. Early information on crop type and acreage is necessary to forecast agricultural water demand during the summer season (Mo et al., 2005; Reichstein et al., 2007). Despite the need for information delivered in near-real time during the crop season, official figure and statistics are usually provided after the end of the growing season, since data have to be collected, verified and compiled into a database.
Satellite remote sensing is a unique source of data for the identification of crop types over large areas, as described in the last two decades in scientific literature (e.g. Ortiz et al., 1997; Pohl and Van Genderen, 1998; De Wit and Clevers, 2004; Ok et al., 2012; Villa et al., 2015). A number of factors influence the accuracy of satellitebased crop maps: i.e. the spatial resolution of the imagery, the classification method, and the production time horizon, i.e. the temporal extent of the dataset and phenological stages covered (HubertMoy et al., 2001; Van Niel and McVicar, 2004; Duveiller and Defourny, 2010). Cultivated crops and site characteristics regulate the selection of the most suitable satellite dataset.

Medium resolution data $(10-30 \mathrm{~m}$, e.g. Landsat) gives better results at local/regional scales and over fragmented landscapes (e.g. Murty et al., 2003; Conrad et al., 2014). Duveiller and Defourny (2010) and Yang et al. (2011) demonstrated that spatial resolution in the range 10-140 m could be considered an optimal choice for a wide range of agricultural landscapes.

\section{MATERIALS AND METHODS}

\section{Study area}

The Study area lies between 23o16' to 24036' N coordinates and $78027^{\prime}$ to $790^{\prime} 40^{\prime} \mathrm{E}$ coordinates with respect to the projection of zone no. 43N UTM on WGS 84 datum. It is covering approximately $5133 \mathrm{Sq}$. km. area. Its elevation range between 286.59 and 882.2 above MSL. The normal annual rainfall of Narsinghpur district is $1192.1 \mathrm{~mm}$. There are four tehsils fall under this district namely Narsinghpur, Gotegaon, Gadarwara \& Kareli and the district further divided into six administrative blocks namely Saikhera, Babai Chichali, Chawarpatha , Kareli, Narsinghpur \& Gotegaon. The study area is illustrated in Fig-1.

\section{Data used}

Satellite data of IRS P6 LISS III of 10th January, 2006 (Path 99 and Rows 55 and 56) and Landsat 8 of 1 st \& 8th February 2015 (Path 144 and 145 and Row 44) of the same season were used for the above case study. The study area falls in Sheet No. 55I and 55J with the Scale of 
1:250000 published by Survey of India. The other ancillary data, i.e. Land use/Land cover map of study area were used in the present study (Table-1).

\section{Methodology}

The methodology flowchart is illustrated in Fig-2. Different registrations for a specific sensor, after preprocessing, form a "multivariate image set". These data contain two types of information: spectral-temporal and spatial-contextual. The spectral-temporal information can be extracted with a supervised Maximum Likelihood algorithm (Duda et al.2000), resulting in a per-pixel classification.

The spatial information can be derived by means of a signature data set collection on the basin of histogram group. On the ideal situation, these group correspond with parcels on the grounds. In this study the segmentation was applied with supervised classification tool which is present in ERADAS Imagine software. Classification and the segmentation are combined using signature dataset collection of different crop type reflectance. This procedure determines for each parcel the pre-dominant class and assign all Pixels of the parcel to this modal class. By reducing speckle and errors in the vicinity of field boundaries, this application enhances the accuracy and legibility of the final map.

The ground truth data needed for the calibration of supervised classifications were collected in two field surveys in before classification and after classification. The garmin GPS handset and the associated software were used for the surveys. During the field surveys, large parcels or plots corresponding different crops were selected and identified and demarcated in FCC to form a ground truth vector GIS. Two mappings as per year 2006 and 2015 to estimate the areas changes of crops.

\section{Classification Procedure}

The digital image processing of satellite data has been carried out using ERDAS IMAGINE 9.2 software and crop cover maps of 2006 and 2015 were prepared following on screen visual interpretation method. In the level - I classification, six land use/land cover classes, i.e., built-up land, agriculture, forest, wastelands, open/fallow land and water bodies have been identified. In level - II classification, Extraction of agriculture area as area of interest (AOI) and overlay on False Colour Composite (FCC) image. In level - III classification, Agriculture class have been further classified. The wheat crop, gram crop, sugarcane and other crops have been identified under agriculture class. In level - IV, Change detection in the crop cover was carried out between 2006 and 2015 .

\section{RESULT AND DISCUSSIONS}

Crop Cover Analysis for 2006 and 2015

The total agricultural area increased by about 6.31 per cent during the period from 2006 to 2015 . In the year 2015 , the agricultural area in the district was about 264284.8 ha which was about 32395.33 ha more than in 2006 (231889.47 ha).

The crop map of 2006 shows that the total wheat area in study area in 2006 was only $10.07 \%$ (51665.57 ha) of the total geographical area (Table-2). The dominant crop class in district was gram 136442.68 ha i.e. $26.58 \%$ of the total area under the district. This shows that the agricultural area of district was a gram dominant (Fig-3). Sugarcane and other crop classes cover an area of 25555.27 ha (4.98\%) and 18225.95 ha (3.55) respectively. In year 2015, the dominant crop of the district was wheat 108112 ha i.e. $21.06 \%$ of the total study area. The total area under gram and sugarcane was 87428.6 and 54997.2 ha respectively (Fig-4). Only $2.68 \%$ of the total area was under other crops that means it has very thin vegetative cover.

The study shows a large scale change during 2006 to 2015 in Narsinghpur. The wheat area which was just $10.07 \%$ in 2006 increased to about $21.06 \%$ in 2015 . Sugarcane area also increased from $4.98 \%$ to $10.71 \%$ during 2006 to 2015. This wheat and sugarcane area expanded on to the gram and other crops and hence the gram area reduced to $17.03 \%$ in 2015 from $26.58 \%$ in 2006 and other crops area reduced to $2.68 \%$ in 2015 from $3.55 \%$ in 2006 (Table-2).

\section{Crop cover changes}

Fertile alluvial soils and the availability of water through canals as well as ground water sources support intensive agricultural activity in the region. The population pressure, economic potential of the region and the entrepreneurial attitude of a majority of the farmers in the region have significantly transformed the crop cover pattern of the area, especially during the recent years.

A study has been conducted by Rao et al. (1991) which was based on the interpretation of IRS-1A LISS-I image on 1:250,000 scale. They observed that due to changes in cropping pattern from seasonal crops to long term crops, there has been an increase in the cropping intensity by about $160 \%$ in the deltaic region during 1980s when compared to the earlier period. In the present study also the Landsat imagery of 2015 are found to be useful, especially for identifying broad categories of crop cover required for the purpose of this study.

Large-scale exploitation of groundwater resources during the recent years has increased the area of more water requirement crops possible instead of less water requirement crops earlier. Further, the area under 
wheat and sugarcane has increased during the last ten years: This is evident from the observation of the satellite imagery. While 2006 image (Fig-3) shows maximum area under seasonal gram crop, the 2015 satellite image (Fig-4) shows wheat cover in many parts of the study area.

The progressive increase in the wheat crop as well as sugarcane crop extent in the district is revealed by the area statistics obtained from the G1S analysis of the two datasets (Table 2). During the period between 2006 and 2015, there has been an increase in the area under wheat by 56446.43 ha $(109.25 \%)$ and sugarcane by 29441.93 ha $(115.21 \%)$, respectively, while the extent of gram has decreased by 49014.08 ha $(-35.92 \%)$ and other crops by 4478.95 ha $(-24.57 \%)$, respectively. The increase in the sugarcane extent, is mainly due to the large-scale exploitation of groundwater resources and water available in the canal of the study area. In fact, an area of about 25555.27 ha, which was mainly occupied in 2006 by wheat, gram and other crops, has been converted into sugarcane area that contain water almost throughout the year. As such, the extent of sugarcane has increased considerably in the study area.

\section{CONCLUSION}

Based on, a supervised classification method is proposed for identifying crops at the level in agricultural land by using multispectral data. It is concluded that the Agricultural practices in the study area have altered significantly in 10 years. The crop area overlapped in the fallow/barren area was evident by the development in of the canal in the area and augmentation of area covered by of wheat $(109.25 \%)$ and sugarcane $(115.21 \%)$ crop while decline in gram $(-35.92 \%)$ and other cropped area ( $24.57 \%$ ).

The Change Detection analysis is an efficient way of describing the changes observed in each category. Study implies that in the year 2006 agricultural area were found 231889.47 ha, while in the year 2015 area were 264284.8 ha, which is easily identified through classification that open /fallow land converted in to Agriculture/other vegetation. The supervised method gives quite satisfactory results for vegetation varying in densities and also for scattered vegetation from a multispectral remote sensing image.

Our findings demonstrate that near real-time, in season crop mapping is feasible using satellite data with suitable spatial and temporal resolution in a simple, operational and inexpensive way. This early in-season crop map could be useful to support agricultural practices and management, especially for supporting the analysis of water demand for major crops during dry summer months.

\section{ACKNOWLEDGEMENT}

Authors are highly thankful to data provider national and international agencies. Also acknowledge the RS and GIS Lab of Department of Soil and Water Engineering, College of Agricultural Engineering, JNKVV University482004, providing complete lab facility for study and research work.

\section{REFERENCES}

[1] Conrad C., Dech S., Dubovyk O., Fritsch S., Klein D., Löw F. Zeidler J. (2014) - Derivation of temporal windows for accurate crop discrimination in heterogeneous croplands of Uzbekistan using multitemporal RapidEye images. Computers and Electronics in Agriculture, 103: 63-74. doi: http://dx.doi.org/10.1016/j.compag.2014.02.003.

[2] De Wit A.J.W., Clevers J.G.P.W. (2004) Efficiency and accuracy of per-field classification for operational crop mapping. International Journal of Remote Sensing, 25 (20): 4091-4112. doi: http://dx.doi.org/10.1080/01431160310001619580.

[3] Duda, R., Hart, P., Stork, D., 2000. Pattern classification (Second Edition). Wiley-Interscienec, $654 \mathrm{p}$.

[4] Duveiller G., Defourny P. (2010) - A conceptual framework to define the spatial resolution requirements for agricultural monitoring using remote sensing. Remote Sensing of Environment, 114 (11): 2637-2650. doi: http://dx.doi.org/10.1016/j.rse.2010.06.001.

[5] Eerens, H., Dong, Q., Ozer, P., Li, X., 2003 A field-based crop and land use map over Sanjiang plain in Heilongjiang derived from multi-temporal imagery of Landsat7-ETM+. Cybergeo: European Journal of Geography, N.247. http://www.cybergeo.eu/index4020.html (accessed 19 Sep. 2003).

[6] Foerster S., Kaden K., Foerster M., Itzerott S. (2012) - Crop type mapping using spectral-temporal profiles and phenological information. Computers and Electronics in Agriculture, 89: 30-40. doi: http://dx.doi.org/10.1016/j.compag.2012.07.015.

[7] Hubert-Moy L., Cotonnec A., Le Du L., Chardin A., Perez P. (2001) - A comparison of parametric classification procedures of remotely sensed data applied on different landscape units. Remote Sensing of Environment, 75: 174-187. doi: http://dx.doi.org/10.1016/S0034-4257(00)00165-6.

[8] Mo X., Liu S., Lin Z., Xu Y., Xiang Y., McVicar T.R. (2005) - Prediction of crop yield, water 
consumption and water use efficiency with a SVATcrop growth model using remotely sensed data on the North China Plain. Ecological Modelling, 183 (2): 301-322. doi: http://dx.doi.org/10.1016/j.ecolmodel.2004.07.032.

[9] Murthy C.S., Raju P.V., Badrinath K.V.S. (2003) Classification of wheat crop with multitemporal images: performance of maximum likelihood and artificial neural networks, International Journal of Remote Sensing, 24 (23): 4871-4890. doi: http://dx.doi.org/10.1080/0143116031000070490.

[10] Ok A.O., Akar O., Gungor O. (2012) - Evaluation of random forest method for agricultural crop classification. European Journal of Remote Sensing, 45 (3): 421-432. doi: http://dx.doi.org/10.5721/EuJRS20124535.

[11] Ortiz M.J., Formaggio A.R., Epiphanio J.C.N. (1997) - Classification of croplands through integration of remote sensing, GIS, and historical database. International Journal of Remote Sensing, $18 \quad$ (1): 95-105. doi: http://dx.doi.org/10.1080/014311697219295.

[12] Pohl C., Van Genderen J.L. (1998) - Multisensor image fusion in remote sensing: concepts, methods and applications. International Journal of Remote Sensing, $19 \quad$ (5): $\quad 823-854 . \quad$ doi: http://dx.doi.org/10.1080/014311698215748.

[13] Rao, D. P., Raghavaswamy, V., Gautam, N. C., Ravishankar, G., Suresh, L. S. and Mujtaba, S. M. (1991). Land use patterns in deltas of east coast with special' reference to Godavari and Krishna river deltas, Memoirs Of Geol. Soc. of India, No. 22, pp. 51-56.
[14]Reichstein M., Ciais P., Papale D., Valentini R., Running S., Viovy N., Cramer W., Granier A., Ogée J., Allard V., Aubinet M., Bernhofer C., Buchmann N., Carrara A., Grunwald T., Heimann M., Heinesch B., Knohl A., Kutsch W., Loustau D., Manca G., Matteucci G., Miglietta F., Ourcival J.M., Pilegaard K., Pumpanen J., Rambal S., Schaphoff S., Seufert G., Soussana J.-F., Sanz M.-J., Vesala T., Zhao M. (2007) - Reduction of ecosystem productivity and respiration during the European summer 2003 climate anomaly: a joint flux tower, remote sensing and modelling analysis. Global Change Biology, 13 (3): 634-651. doi: http://dx.doi.org/10.1111/j.1365-2486.2006.01224.x.

[15] Van Niel T.G., McVicar T.R. (2004) - Determining temporal windows for crop discrimination with remote sensing: a case study in south-eastern Australia. Computers and Electronics in Agriculture, $45 \quad$ (1): 91-108. doi: http://dx.doi.org/10.1016/j.compag.2004.06.003.

[16] Villa P., Stroppiana D., Fontanelli G., Azar R., Brivio P.A. (2015) - In-season mapping of crop type with optical and X-band SAR data: a classification tree approach using synoptic seasonal features. Remote Sensing, 7 (10): 12859-12886. doi: http://dx.doi.org/10.3390/rs71012859.

[17] Yang C., Everitt J.H., Murden D. (2011) Evaluating high resolution SPOT 5 satellite imagery for crop identification. Computers and Electronics in Agriculture, $75 \quad$ (2): 347-354. doi: http://dx.doi.org/10.1016/j.compag.2010.12.012.

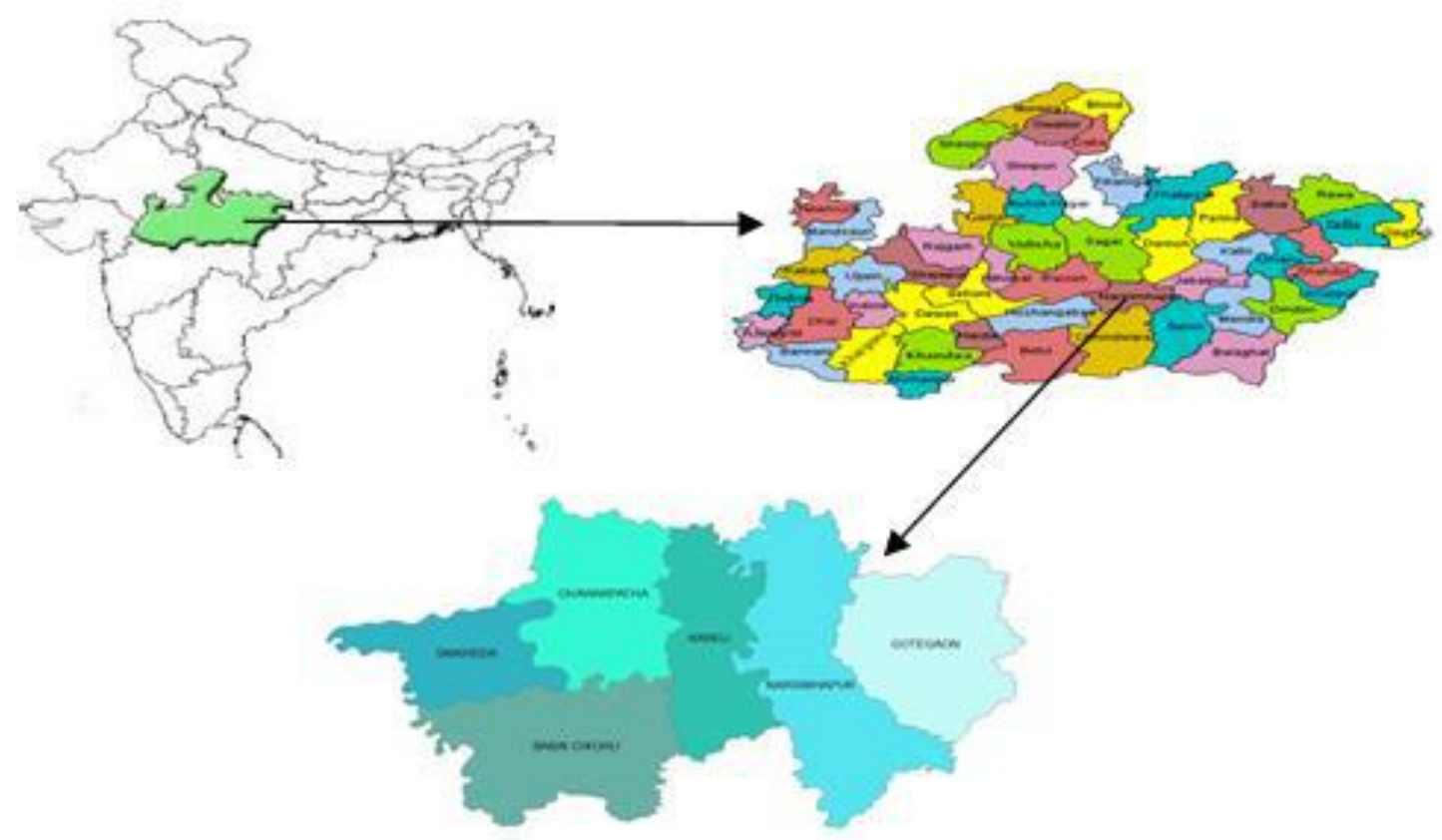

Fig.1: Location map of study area 


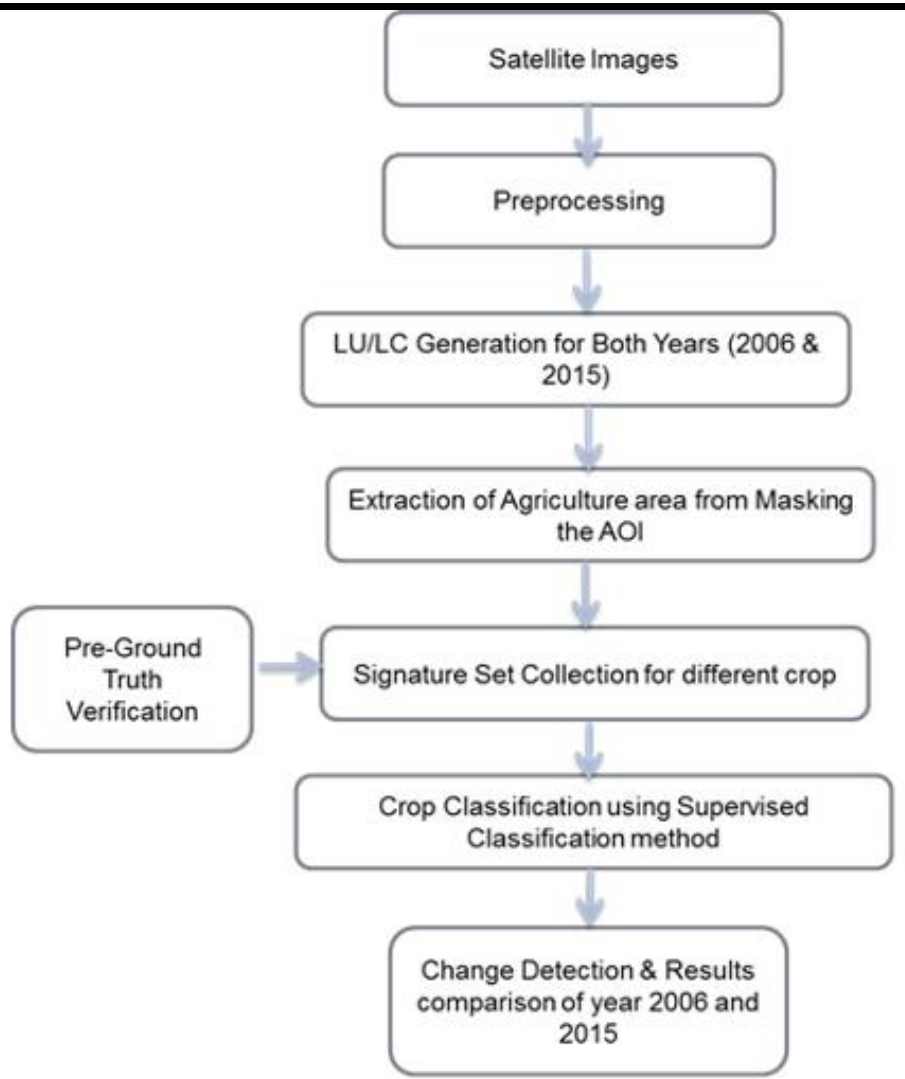

Fig.2: Methodology for extraction of crop data and change detection from imagery

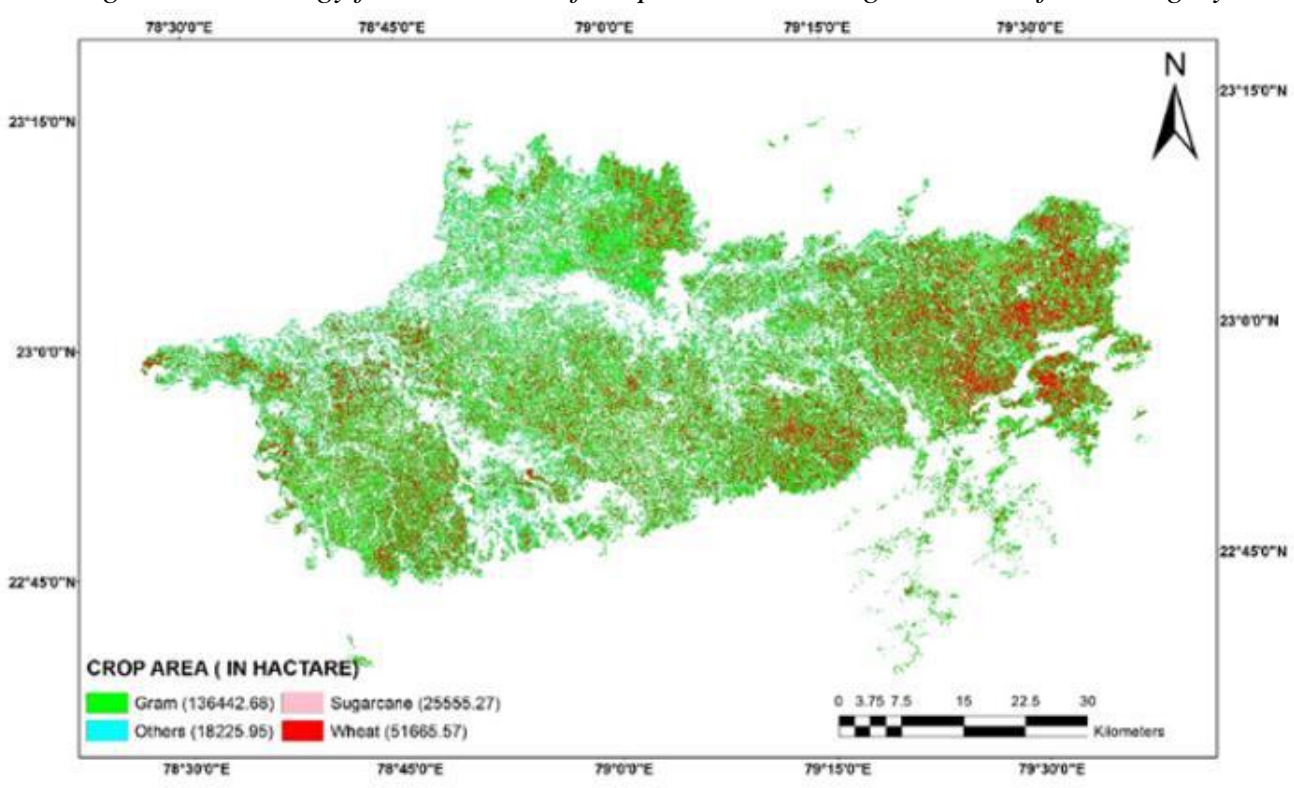

Fig.3: Crop Map of Narsinghpur District (Rabi Season-2006)

Table.1: Details of Satellite Image used for the study

\begin{tabular}{|l|l|l|l|l|}
\hline S. No. & Year & Satellite & $\begin{array}{l}\text { Spatial } \\
\text { resolution }\end{array}$ & Source \\
\hline $\mathbf{1}$ & February,2015 & Landsat 8 & 30 meter & https://earthexplorer.usgs.gov/ \\
\hline $\mathbf{2}$ & January,2006 & LISS III & 23.5 meter & http://www.nrsc.gov.in/ \\
\hline
\end{tabular}




\begin{tabular}{|l|c|c|c|c|c|c|}
\hline \multirow{2}{*}{$\begin{array}{c}\text { Crops } \\
\text { Name }\end{array}$} & \multicolumn{2}{c|}{$\begin{array}{c}\text { LISS 3 Data } \\
(\mathbf{2 0 0 6})\end{array}$} & Landsat Data (2015) & \multicolumn{3}{c|}{ Difference } \\
\cline { 2 - 7 } & $\begin{array}{c}\text { Area } \\
\text { (in ha) }\end{array}$ & $\begin{array}{c}\text { Area } \\
(\boldsymbol{\%})\end{array}$ & $\begin{array}{c}\text { Area } \\
\text { (in ha) }\end{array}$ & $\begin{array}{c}\text { Area } \\
(\boldsymbol{\%})\end{array}$ & $\begin{array}{c}\text { Area } \\
\text { (in ha) }\end{array}$ & $\begin{array}{c}\text { Percentage (\%) change } \\
\text { w.r.t. 2006 }\end{array}$ \\
\hline Wheat & 51665.57 & 10.07 & 108112 & 21.06 & 56446.43 & +109.25 \\
\hline Gram & 136442.68 & 26.58 & 87428.6 & 17.03 & -49014.08 & -35.92 \\
\hline Sugarcane & 25555.27 & 4.98 & 54997.2 & 10.71 & 29441.93 & +115.21 \\
\hline Others & 18225.95 & 3.55 & 13747 & 2.68 & -4478.95 & -24.57 \\
\hline Total Agricultural Area & $\mathbf{2 3 1 8 8 9 . 4 7}$ & 45.18 & $\mathbf{2 6 4 2 8 4 . 8}$ & 51.49 & 32395.33 & +13.97 \\
\hline Total Geographical Area & $\mathbf{5 1 3 3 0 0}$ & & & & & \\
\hline
\end{tabular}

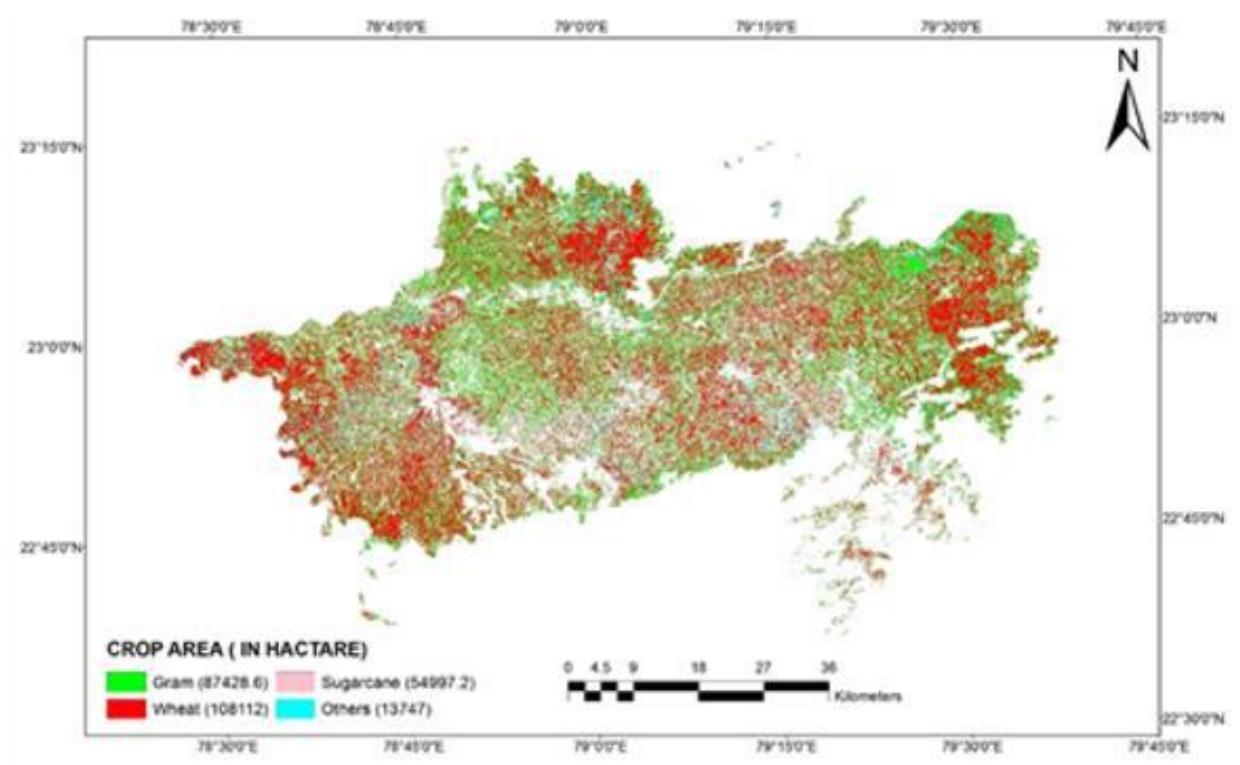

Fig.4: Crop Map of Narsinghpur District (Rabi Season-2015) 